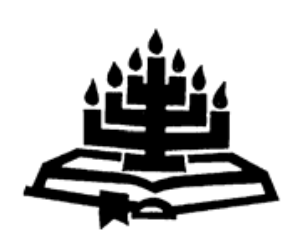

\title{
'n Kontekstuele uitleg van Psalm 110 binne sy historiese raamwerk
}

\author{
J.J. de Bruyn \& D.J. Human \\ Departement Ou-Testamentiese Wetenskap \\ Universiteit van Pretoria \\ PRETORIA \\ E-pos: melkhoutkraal@hotmail.com \\ dirk.human@up.ac.za
}

\begin{abstract}
A contextual exegesis of Psalm 110 in its historical framework
\end{abstract}

Psalm 110 is the psalm that is most revered to in the New Testament. The question can be asked whether the New Testament is the only key to the understanding of Psalm 110. Naturally, the exegetic model that one uses will have an influence on our understanding of the Psalm. The question that will be observed in this article is whether there can be another figure, in addition to Jesus Christ, that can be a priest from the order of Melchizedek. If so, that can shed an alternative light on Psalm 110 from that of the New Testament.

\section{Opsomming}

\section{'n Kontekstuele uitleg van Psalm 110 binne sy historiese raamwerk}

Psalm 110 is sekerlik die psalm wat die meeste in die Nuwe Testament aangehaal word. Hierdie feit kan aanleiding gee tot die vraag of die Nuwe Testament die enigste sleutel is tot die verstaan van Psalm 110. Uiteraard sal die eksegetiese model wat gebruik word 'n invloed hê op die verstaan van die Psalm. In hierdie artikel sal die moontlikheid ondersoek word of daar enige ander figuur is, behalwe Jesus Christus, wat 'n priester volgens die orde van Melgisedek kan wees. Indien daar is, sal dit aan Psalm 110 'n ander betekenis gee as wat die Nuwe Testament daaraan gee. 


\section{Inleiding}

Die moontlikheid dat die Dawidiese konings opvolgers was van 'n Jebusitiese priester-koningsdinastie en dat hulle self hierdie priesterkoningskap oorgeneem het, is 'n teorie wat in die lig van die komende Bybelvertaling waarmee Afrikaanse kerke in Suid-Afrika tans besig is, weer ondersoek behoort te word. Die rede hiervoor is dat die hermeneutiese sleutel wat gebruik word, die vertaling van die teks sal beïnvloed. In hierdie artikel sal die moontlikheid van ' $n$ Dawidiese koning as priester volgens die orde van Melgisedek op 'n diachroniese wyse ondersoek word. Die ondersoek in hierdie artikel sal ook beperk word tot die geskiedenis van Dawid se koningskap, soos dit in 1 en 2 Samuel en 1 en 2 Konings geskets word.

\section{Melgisedek}

In Psalm 110:4 speel die priesterorde van Melgisedek, 'n baie belangrike rol. Van Melgisedek word op net een ander plek in die Ou Testament vertel, naamlik in die verhaal van Abraham wat sy broerskind Lot red uit die hand van Kedor-Laómer, nadat laasgenoemde Sodom en Gemorra ingeneem het. Hierdie verhaal word in Genesis 14 geskets.

Van Melgisedek word vertel dat hy die koning van die stad Salem was. Ek stem met Johnson (1955:32-33) saam as hy hierdie antieke stad aan die latere stad Jerusalem met sy Jebusitiese bevolking gelykstel (vgl. Stuhlmueller, 2002:80). In ooreenstemming met die meeste ander antieke Oosterse volke, blyk dit dat Melgisedek ook 'n

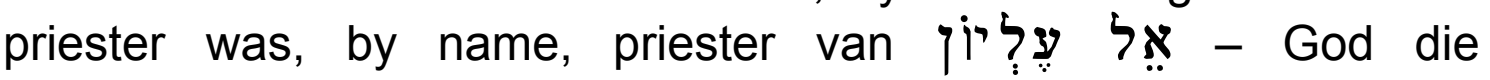
Allerhoogste. Gewoonlik het die konings van die antieke Oosterse volke almal die amp van hoëpriester beklee (vgl. Johnson, 1955:4246). Israel was dus in 'n sekere sin uniek, omdat by hulle die status van hoëpriesterskap nooit aan enige koning in die Ou Testament toegeken is nie (vgl. Anderson, 1979:352). Anders as by hulle bure, is die regeerfunksie (die koningskap) en die hoëpriesterskap van mekaar geskei. Vanuit Psalm 110 lyk dit egter wel moontlik dat die koning sekere priesterlike funksies gehad het.

Die moontlikheid bestaan dat die naam Melgisedek eerder verdeel moet word in die eienaam Milki en dan die titel sedek (vgl. Johnson, 1955:33). In Josua 10 word van nog 'n koning van Jerusalem vertel, naamlik Adoni-Sedek. Adoni-Sedek kan vertaal word met: my heer is geregtigheid/regverdig. In hierdie sin sou Melgisedek nie noodwendig met koning van geregtigheid vertaal hoef te word nie, maar eerder: die koning is geregtigheid/regverdig; of dan: Milki 
(eienaam), die regverdige. Johnson (1955:31-33) meen dat daar genoeg argeologiese bewyse is om sedek as 'n titel te beskou. Hierdie titel sou in verband gebring kon word met die koning se taak en funksies binne die Jebusitiese samelewing. As koning was die heerser van Salem sekerlik verantwoordelik vir die handhawing van reg en geregtigheid.

Daar is ook geleerdes wat poog om sedek aan 'n Kaänanitiese godheid te verbind (vgl. Anderson, 1979:371). Alhoewel daar nie genoeg bewyse hiervoor is nie, sou Melgi-sedek dan verstaan kon word as iemand - 'n koning met die naam Milki, wat koning is deur die wil van die god Sedek. Hierdie verklaring sou dan verbind kon word aan die algemene Oosterse opvatting dat die konings deur die gode aangestel is.

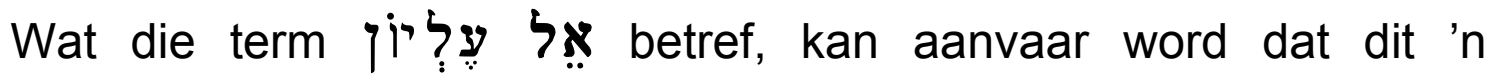
samestelling is van twee goddelike name, naamlik El en Eljôn - god en allerhoogste. Johnson (1955:44) meen dat dit 'n manier is om na 'n oppergod te verwys. Waarskynlik was dit die godheid wat voor Dawid se inname van die stad Jerusalem deur die Jebusiete aanbid is.

Op verskeie plekke in die Ou Testament word hierdie selfde godsname egter ook vir die God van Israel gebruik. As selfstandige Godsnaam, kom צִ צִ עי יוֹ voor in Deuteronomium 32:8 en Psalm 9:3. Dit word selfs in verbinding met יהוה gebruik (bv. Ps. 7:18 en Ps. 47:3). In Daniël word drie keer na die Here verwys as die Allerhoogste God (vgl. Dan. 3:26; 4:2 en 5:21). Ook Abraham gebruik die term God die Allerhoogste, wanneer hy na die Here (יהוה) verwys (vgl. Gen. 14:22). Volgens die wyse waarop die Ou Testament die verhaal van Abraham en Melgisedek aanbied, bestaan daar 'n moontlike verband tussen die God van Abraham en dié van Melgisedek. Hierdie verband kan ook wyer getrek word ten opsigte van die God van Israel, יהוה. Volgens Eksodus 6:2 het die Here nooit sy naam יהוה (Ek is - Jahwe) aan Abraham, Isak of Jakob bekend gemaak nie. Dit is eers aan Moses wat God Homself as $E k$ is openbaar en tog gebruik Abraham hierdie naam vir God en vir die God van Melgisedek. Die rede is waarskynlik dat latere strorievertellers of die redakteurs van hierdie verhaal, bloot aanvaar het dat die God van Israel, יהוה, die God van Abraham en die God van Melgisedek dieselfde God was (vgl. Hinson, 1997:36-38). 'n

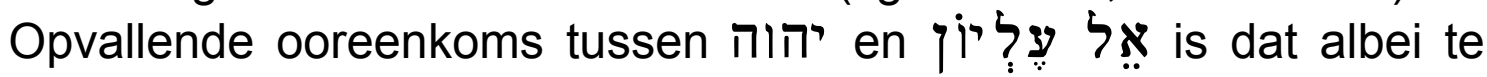


doen het met hoë plekke, byvoorbeeld 'n berg. So verskyn יהוה aan Moses op die berg Horeb (Sinai). Ook die Tien Gebooie word in Eksodus 19 en 20 vanaf die berg Sinai, deur God aan Israel gegee.

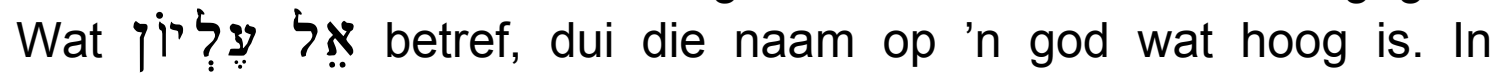
2 Samuel 7 word dit vertel dat Jerusalem op 'n berg gebou was, naamlik Sion. Die Arameërs verwys in 1 Konings 20:23 ook na die God van Israel as 'n Berggod. In Psalm 48 word יהוה en Sionsberg spesifiek aan mekaar verbind. In verskeie van die profete word Sion ook die berg van יהוה genoem (vgl. Joël 3:17; Miga 4:1; 4:2 en Sag. 8:3). Die moontlikheid bestaan dus dat dieselfde God deur verskillende volke onder verskillende name aanbid is (vgl. Boshoff, Scheffler \& Spangenberg, 2000:58-62). Israel en die Jebusiete (Abraham en Melgisedek) kon dus dieselfde God aanbid het.

Met alles in ag genome, kan aanvaar word dat daar in Jerusalem 'n sterk godsdienskultus was vóórdat koning Dawid die stad ingeneem het (vgl. 2 Sam 5). Johnson (1955:32-46) noem self die moontlikheid van 'n koninklike tempel of heiligdom in die stad. Hierdie godsdienskultus is in stand gehou deur 'n koninklike lyn van priesters waarvan Melgisedek deel was. Zimmerli (1987:76) sluit hierby aan as hy meen dat daar selfs moontlike godsverskynings in Jerusalem was vóór Dawid se oorname van die stad. Wat betref die Godheid wat in Jerusalem aanbid is vóór Dawid se inname van die stad, kan aanvaar word dat daar sterk ooreenkomste was tussen יהוה, ạ as God van Israel en as God van Jerusalem en Melgisedek.

\section{Dawid se inname van Jerusalem (Salem)}

In 2 Samuel 5 word die verhaal vertel van Dawid se inname van die stad Jerusalem. Dawid wat alreeds sewe jaar koning van Juda was, is pas ook gesalf as koning oor Noord-Israel. Met die salwing van Saul as koning, het Israel se regeringsvorm stadig begin verander. Die stamme het wegbeweeg van 'n konfederale stelsel, waar die oudstes in die stadpoort die stamme regeer het (vgl. Anderson, 1975:180-182). Selfs al was daar rigters voor Saul, is dit vanuit die boek Rigters duidelik dat hierdie tipe regeerders bitter selde, indien ooit, oor al twaalf stamme "regeer" het. Die enigste ware samebindende faktor tussen die stamme, was hulle gemeenskaplike geloof in יהוה, die God van Abraham, Isak en Jakob. Die feit dat die twaalf stamme ná Saul se dood weer opgebreek het, wys dat Saul nooit regtig die stamme as één volk kon verenig nie. Ook Dawid kon nie dadelik daarin slaag om die stamme te verenig nie. Eers is hy 
net as koning oor Juda gesalf. Vir sewe jaar het hy in Hebron regeer, terwyl Isbóset, die seun van Saul, oor die res van Israel regeer het. Dit is eers met Isbóset se dood dat die oudstes van Noord-Israel Dawid se koningskap aanvaar het (vgl. 2 Sam. 4 en 5).

In 'n poging om die twaalf stamme te verenig, het Dawid twee dinge gedoen. Eerstens het hy vir Israel 'n gemeenskaplike hoofstad gesoek. Vanuit hierdie hoofstad sou Dawid sy koningskap kon versterk. As hoofstad het Dawid na 'n stad gesoek wat tradisioneel nie tot die grondgebied van een van die stamme behoort het nie. Jerusalem, met sy Jebusitiese inwoners en priester-koning, het geblyk die ideale plek te wees. Van Dawid se veldslag teen die stad word onder andere in 1 Kronieke 11 vertel. Dawid het die stad met sy privaat weermag ingeneem, waarna dit sy persoonlike eiendom geword het, bekend as die Stad van Dawid (vgl. 2 Sam. 5:7 \& Hinson, 1997:93).

$\mathrm{Na}$ Dawid se verowering van Jerusalem met sy godsdienskultus, wat hierdie outeur aanvaar verwant was aan dié van Israel, neem hy 'n tweede stap om die twaalf stamme te verenig. In 1 Kronieke 1517 word vertel dat Dawid ook die openbare godsdiens van Israel gereël het. In die middel van hierdie godsdienshervorming, neem die nuwe hoofstad, Jerusalem, 'n sentrale plek in. Die verbondsark word ook na Jerusalem gebring, terwyl die priesters ook in ordes, volgens hulle families, ingedeel word. Dawid wou ook 'n tempel vir die Here bou, maar hy is dit nie toegelaat nie (vgl. 1 Kron. 17). Nadat Dawid die verbondsark na Jerusalem gebring het, het die Stad van Dawid ook bekend geword as Sion, die stad van God. Met die verskuiwing van Israel se gemeenskaplike aanbiddingsplek vanaf Silo na Jerusalem, is politieke en godsdienstige mag op gelyke voet geplaas. Die Here se woonplek was daar waar die koning se woonplek is (Anderson, 1975:182). Dawid het dus Israel as 'n volk saamgesnoer rondom die stad Jerusalem, wat moes dien as sentrum van sy koningskap, maar wat ook moes dien as sentrum vir 'n gemeenskaplike godsdienskultus. Koningskap en godsdiens was dus die twee elemente wat Dawid gebruik het om Israel as volk saam te snoer. Dit wil dus lyk asof Dawid, op die spoor van sy voorganger Melgisedek, godsdiens en koningskap met mekaar begin vermeng het (vgl. Anderson, 1979:367; Stuhlmueller, 2002: 80). Die outeur aanvaar dat Melgisedek se priester-koningskap as agtergrond van hierdie vermenging gesien kan word.

In ooreenstemming met Dawid se godsdienshervormings en sy indeling van die priesters in ordes, word in 2 Samuel 8:18 genoem dat Dawid se seuns priesters was. Hulle was dus priesters, nie uit 
die stam van Levi nie, maar wel uit die stam van Juda. Dawid se seuns het dus as prinse ook die priesteramp bedien. Hulle was dus priester-prinse, met die potensiaal om 'n priester-koning te word, net soos Melgisedek van ouds. As God dan die priesteramp aan die stam van Levi opgedra het, hoe het Dawid se seuns priesters geword?

In 2 Samuel 8:17 word ook vir die eerste keer melding gemaak van die priester Sadok wat saam met Abjatar priester was. Abjatar word vermeld in die vertelling van Saul se uitwissing van die priesterstad, Nod (vgl. 1 Sam. 21 en 22). Abjatar word genoem as die enigste oorlewende van hierdie priesterslagting. Sy voorgeslagte kan verbind woord aan Eli, die hoëpriester in die tyd toe Samuel 'n seun was. Van Sadok word daar egter vir die eerste keer eers melding gemaak ná Dawid se verowering van Jerusalem. Oor wie Sadok was en waar hy vandaan kom, bestaan daar verskeie teorieë (vgl. De Vaux, 1991:373-374). Daar is die moontlikheid dat Sadok priester in Jerusalem was nog voor Dawid die stad ingeneem het. Weens Dawid se respek vir Jerusalem se godsdiens, wat nóu verwant was aan dié van Israel, is Sadok toegelaat om sy priesterlike werk onder Dawid se regering voort te sit. As dit waar is, is Sadok nie oorspronklik van Levitiese afkoms nie. Sy verbintenis aan die stam Levi kan dus eers 'n latere ontwikkeling wees (vgl. Hinson, 1997:103).

Die Ou Testament bied twee stambome vir die priester Sadok. Hy word aan Aäron verbind (vgl. 1 Kron. 5:29-34 en 6:35-38), maar ook aan die priester Eli (vgl. 2 Sam. 8:7). Sadok kon egter nie familie van Eli wees nie, aangesien die Ou Testament dit baie duidelik stel dat Sadok se aanstelling as hoëpriester as straf vir die huis van Eli moes dien (vgl. 1 Kon. 2:27, 1 Sam. 2:27-36 en 3:11-14). 'n Ander moontlikheid is dat Sadok in die Levietestam opgeneem kon word deur aanneming. As Abraham in Genesis 15 sy slaaf Eliëser as sy seun en erfgenaam kon aanneem, kon Sadok moontlik ook op soortgelyke wyse in die Levietestam opgeneem word. Die outeur aanvaar dus dat Sadok nie 'n Leviet van herkoms was nie. Dit sou beteken dat daar twee lyne van priesters was, naamlik die Sadokiete en die Leviete. Die moontlikheid bestaan dat Sadok die priester-koning van Jerusalem was ten tye van Dawid se verowering van Jerusalem (vgl. Johnson, 1955:42, 46). Sy naam herinner baie sterk aan die titels van die Jebusitiese konings (vgl. Melgisedek en Adoni-sedek), as die handhawer van geregtigheid.

Israel het nie as volk in 'n vakuum bestaan nie. Hulle was deel van 'n groter gebied, naamlik die Midde-Ooste - hulle was deel van 'n 
breër Semitiese samelewing. Dit is dus net logies dat Israel seker gemeenskaplike gebruike met die van ander buurvolke gedeel het. Wat rituele en godsdienstige gebruike betref, is dit dus moontlik dat iemand soos Dawid sekere van die buurvolke se gebruike kon oorneem en herinterpreteer, om dit so deel te maak van die Israelitiese kultus. As in ag geneem word dat die godheid van sekere volke, soos die Jebusiete, baie met dié van Israel ooreengestem het, sou so 'n uitruiling en oorname van gebruike tussen Israel en ander volke nie vergesog wees nie. Die outeur aanvaar dus saam met Anderson (1979:367) dat Dawid baie van sy godsdienshervormings op die lees van sy voorganger Melgisedek geskoei het. In Jerusalem het Dawid te doen gekry met 'n godsdienskultus soortgelyk aan dié van Israel. Daar was dus reeds 'n gevestigde kultus, gestel op 'n berg met die naam Sion. 'n Priester-koning het oor die Jebusiete regeer - 'n priester-koning met 'n titel wat hom moes herinner aan sy taak om reg en geregtigheid in die land te handhaaf.

As dus saam met Anderson (1979:367) aanvaar word dat Sadok oorspronklik ' $n$ Jebusitiese priester was, is dit moontlik dat hy die middel kon wees waardeur Dawid sekere Jebusitiese gebruike ingevoer het. Na sy oorname van Jerusalem, het Dawid ook koning van die stad se Jebusitiese inwoners geword. Polities was Dawid dus die opvolger van Jerusalem se Jebusitiese priester-konings. As opvolger van Melgisedek, het Dawid dus volgens Jebusitiese gebruike, soos sy voorgangers, ook 'n priester-koning geword. Dit kan verklaar waarom Dawid se seuns skielik na sy oorname van Jerusalem, priesters geword het. Weens Dawid en sy seuns se koninklike status sou dit bloot gepas wees as hulle in 'n aparte priesterorde ingedeel word as die Levitiese priesters. Aangesien hulle priesters sou wees op grond van die priesterskap van die Jebusitiese konings, kan hulle saam met Melgisedek in dieselfde priesterorde ingedeel word. So 'n priesterorde kan inderdaad dan 'n orde van Melgisedek genoem word, aangesien hy die eerste Jebusitiese koning is waarvan die Ou Testament vermeld dat hy ook 'n priester was.

As nuwe heerser van Jerusalem het die taak om reg en geregtigheid te handhaaf, nou op Dawid en sy nakomeling geval. Hierdie kultiese funksie van die Jebusitiese priester-koning kan dus die agtergrond wees waarteen die Judese koning, volgens Psalm 72, die opdrag het om reg en geregtigheid te handhaaf. 


\section{Uitleg van Psalm 110}

Prinsloo (1988:179) vat dit saam as hy sê dat ons in Psalm 110 met 'n teokrasie te doen het, want hier word die priesterlike werk en die koninklike funksies gekombineer. By die uitleg van hierdie Psalm moet dus in gedagte gehou word dat dit 'n koningspsalm is (vgl. Kraus, 1960:754). Dit is dus 'n Psalm wat handel oor die Judese koning as die messias van God. In hierdie sin is Psalm 110 'n messiaanse psalm - nie omdat Psalm 110 op die spoor van die Nuwe Testament op Jesus Christus van toepassing gemaak kan word nie, maar spesifiek omdat dit in die eerste plek oor die Judese koning handel. Hiervolgens is die koning wat deur God self aangestel is, se regering 'n vergestalting van die Here se eie regering. Die Here regeer deur die koning as sy gevolmagtigde aardse verteenwoordiger. As gesalfde seun van God is dit die Here self wat aan die koning mag en heerskappy gee. Die koning hoef dus nie vir sy vyande bevrees te wees nie, want God self staan die koning by (vgl. Ps. 2). As koningspsalm beskryf Psalm 110 die kroningseremonie van 'n nuwe Judese koning. Dat hierdie Psalm ook saam met ander koningspsalms elke jaar as herdenkingslied gebruik is ter ere van die koning, kan egter nie buite rekening gelaat word nie (vgl. Kraus, 1960:175).

Dawid was die eerste Judese koning wat, op die spoor van sy Jebusitiese voorgangers, Israel se koningskap en priesterlike ordes en funksies met mekaar gekombineer het. As opvolger van sy Jebusitiese voorgangers, was Dawid dus ook priester en koning. As adellikes, is Dawid en sy seuns moontlik onder die koninklike priesterorde van Melgisedek ingedeel. Die outeur aanvaar dus die moontlikheid dat Psalm 110, of 'n deel daarvan, oorspronklik as koningspsalm vir Dawid gedig is in die tyd toe hy Jerusalem verower het. Waarskynlik moes hierdie Psalm Dawid se sentralisering van die Israelitiese godsdiens rondom die Jebusitiese kultus van Jerusalem, ondersteun. Natuurlik kan dit nie buite rekening gelaat word dat hierdie Psalm ook tydens die kroningseremonies van Dawid se nakomelinge gebruik kon word nie. Elke Judese koning was immers, as nakomeling van Dawid, God se messias en daarom kon elke koning met die dag van sy kroning herinner word aan sy taak as priester en koning. Soos wat die verwagting aan 'n komende groot koning, wat soos Dawid Israel se vyande sou verslaan, deur Israel se geskiedenis ontwikkel het, so kon hierdie Psalm met die kroning van elke koning geherinterpreteer word.

Aan die ander kant is dit wel moontlik dat Dawid Psalm 110 gedig het. Dit sou waarskynlik gewees het in die tyd toe sy seun, Salomo, 
die troon bestyg het (vgl. Van der Ploeg, 1974:250). Indien hierdie moontlikheid aanvaar word, is Psalm 110 moontlik deur Dawid aan Salomo opgedra tydens sy kroning.

Wat die kultiese Sitz im Leben van Psalm 110 betref, is daar drie moontlikhede (vgl. Prinsloo, 1988:175). Die mees logiese moontlikheid is dat Psalm 110 te doen het met 'n troonsbestygingseremonie van 'n Judese koning (vgl. Van der Ploeg, 1974:247). Kraus (1960:756) meen dat Psalm 110 as koningspsalm uit die vroegste tye van die Judese monargie dateer en as kroningslied gebruik is. Die moontlikheid bestaan egter ook dat Psalm 110 aan 'n jaarlikse Nuwejaarsfees, soortgelyk aan dié van Babilonië, verbind kan word. Derdens is daar navorsers wat weens die militêre aard van die Psalm, dit aan 'n konkrete veldslag wil verbind. Dit sou verbind kon word aan 'n ritueel vóór die fisiese oorlogsvoering, waar daar alreeds aan die koning oorwinning belowe word weens sy noue verbintenis met die Here. Psalm 2:9 versterk die vermoede van so 'n voor-oorlogse ritueel. In Egipte was die spesifieke gebruik om die name van die farao se vyande op erdepotte te skryf. Tydens 'n magiese ritueel is hierdie potte dan voor 'n oorlog stukkend geslaan as 'n teken van oorwinning.

As aangenome seun van die Here sou die koning sekerlik op hulp van sy Hemelse Vader kon staatmaak. In Psalm 2 word dit geskets dat opstand teen die koning net so goed soos opstand teen die Here is, daarom dat God self betrokke is by die uiteindelike oorwinning van die koning oor sy vyande.

Met betrekking tot die historiese Sitz van Psalm 110, wissel die datering vanaf die tyd van Dawid ( \pm 1000 v.C.) tot in die Makkabese tyd van Simon Makkabeus (142-134 v.C.). 'n Mens kan egter aanvaar dat dié Psalm ontstaan het in die tyd van die Judese monargie vóór die Babiloniese ballingskap. Die psalmopskrif: Van Dawid is dus nie noodwendig 'n aanduiding van die outeur of ontstaanstyd nie, aangesien hierdie opskrif waarskynlik eers ná die ballingskap bygevoeg is (vgl. Prinsloo, 1988:176 \& Van der Ploeg, 1974:250).

\section{- Die opskrif}

Die opskrif kan eerder vertaal word met ' $n$ psalm vir Dawid. Dit ondersteun die gedagte dat Psalm 110 oorspronklik gedig is in die tyd toe Dawid die stad Jerusalem verower het. Dit kon moontlik dien as ' $n$ verering van Dawid se koningskap oor Juda en Israel. Daar moet in gedagte gehou word dat Dawid met die inname van 
Jerusalem ook koning van die Jebusiete geword het. So 'n vertaling van die opskrif, laat die digter egter onbekend. Met inagneming van bogenoemde, kon die digter dalk die priester Sadok self gewees het, veral as aanvaar word dat hy die een sou wees deur wie Dawid die Israelitiese en Jebusitiese kultusse verenig het. As priester en moontlik selfs koning van die Jebusiete, behoort Sadok die funksies en regte van 'n priester-koning waarskynlik die beste geken het. Dit sou dus gepas wees as hy die een was wat Dawid gehelp het om die Israelitiese kultus te skoei op die lees van dié van die Jebusiete.

\section{- Vers 1}

Die digter begin die Psalm deur daarop te wys dat dit die Here is wat die koning aanstel. Deurdat die Here die koning aan sy regterhand laat sit, neem hy die ereplek langs God in. Dit beklemtoon dat die koning die Here se vasaal op aarde is. Die uitdrukking: Kom sit aan my regterhand ... het moontlik spesifiek te doen met die dag waarop die kroonprins as koning die eerste keer die troon van die Here bestyg het. 1 In Egipte word die farao ook soms afgebeeld waar hy op 'n troon aan die regterkant van die godheid sit (vgl. Keel, 1977:240). Die nuwe koning ontvang saam met die Here se uitnodiging om aan sy regterhand te sit ook die versekering dat die Here self sy vyande sal verslaan. As seun en gesalfde van die Here, staan die koning immers onder die beskerming van die Here. As vasaal van die Here verteenwoordig die koning eintlik God se heerskappy oor Israel en hulle vyande, óók daarom dat die Here self betrokke is by die onderwerping van die koning se vyande (vgl. Ps. 2). Die uitdrukking: 'n voetstoel vir jou voete het waarskynlik te doen met die gebruik waar die seëvierende koning soms sy voet ná die oorlog op die nek van sy verslane vyande gesit het (vgl. Jos. 10:24).

\section{- Vers 2}

Hier word weereens beklemtoon dat die koning nie net sy koningskap van die Here ontvang nie, maar ook sy mag en gesag. As die Groot Koning wat vanaf Sion oor die wêreld regeer (vgl. Ps. 48), oorhandig die Here mag en gesag aan sy gesalfde seun om te kan regeer. Van der Ploeg (1974:253) meen dat dit van die koning 'n sakrale persoon maak. As teken van hulle mag het die konings elkeen 'n septer gehad.

1 Vgl. 1 Kronieke 28:5 en 1 Kronieke 29:23. "Salomo het sy plek ingeneem op die troon van die Here ...". 


\section{- Vers 3}

Daar is volgens Prinsloo (1988:177) twee moontlike maniere waarop hierdie vers verstaan kan word. Eerstens kan dit so verstaan word dat dit na die koning se aanneming as seun van God verwys. Dit gaan saam met die twee alternatiewe vertalingsmoontlikhede wat lui: "Op die heilige berge [Sion?] uit die moederskoot van die daeraad het Ek [met ander woorde die Here] jou soos dou verwek", óf: "In heilige feesgewaad, uit die moederskoot van die daeraad is die dou van jou geboorte."

Wat duidelik blyk uit die verstaan van vers 3 , is dat die Israelitiese koningsideologie in teenstelling staan met die koningsideologie van die Ou Nabye Ooste. By Israel se bure is die koning dikwels as ' $n$ goddelike wese beskou (bv. Egipte), omdat hy as 'n fisiese afstammeling van die gode beskou is. By Israel was die koning egter nie 'n fisiese afstammeling van die godheid nie. As mens is hy deur die Here begenadig, deurdat God hom aanneem as sy seun op die dag wanneer hy as koning gesalf word (vgl. Stuhlmueller, 2002:75). Ook Kraus (1960:759) gee voorkeur aan hierdie verstaan van die teksvers. Hy meen dat dit bydra tot die misterie van die verhouding tussen die koning en die Here.

Die alternatiewe verstaan van hierdie vers dui op 'n militêre situasie. Hierdie verstaan van die vers gaan hand aan hand met die vertalingsmoontlikheid: " $U$ volk is gereed vir die dag waarop u u magte monster. $U$ jongmanne is $u$ krag as hulle teen dagbreek aantree, geklee vir die heilige stryd," óf: "U volk sal baie gewillig wees op die dag van u krygsmag; in heilige feesgewade, uit die moederskoot van die dageraad sal vir u wees die dou van $u$ jong manskappe." Volgens Burden (1991:128) is hierdie feesgewade nie gewone militêre uniforms nie. Dit is eerder 'n tipe toga wat deur die priesters gedra is op godsdienstige feesdae. Op hierdie wyse kan die kroning van die nuwe koning dus met die godsdienskultus van Israel geassosieer word.

\section{- Vers 4}

Volgens die vóór-Israelitiese tradisie van Jerusalem, word die nuwe koning ook as priester aangestel. As adellike word die koning nie saam met die gewone Levitiese priesters geklassifiseer nie. Hy word eerder onder die koninklike priesterorde van die Jebusitiese koning, Melgisedek, ingedeel. Net soos by sy aanstelling as koning, is dit die Here self wat die nuwe koning ook as priester aanstel. 
Daar kan aanvaar word dat hierdie priesterlike funksie van die Judese koning meer abstrak was as dié van die Levitiese priesters. Daar word wel gesê dat Dawid se seuns priesters was, maar daar kan aanvaar word dat die koning hom meer op die politiek toegespits het as dat hy, soos 'n Levitiese priester, daaglikse tempeldiens sou verrig. As priester en leier van die volk, het die koning wel die bevoegdheid gehad om in besondere gevalle aan die kultus deel te neem (vgl. byvoorbeeld 2 Sam. 6:14 en 18; 24:25 en 1 Kon. 8:14 en 22). Dit is waarskynlik op grond van die priesterlike mag van die koning, dat Dawid soveel kultiese hervormings kon deurvoer. So ook die latere koning Josia. Uit die verhaal van koning Ussia wat met melaatsheid getref is in 2 Kronieke 26, kan 'n mens aflei dat seker kultiese funksies egter net deur die Levitiese priesters behartig kon word. Die koning se priesterlike bevoegdheid het dus oorvleuel met dié van die Levitiese priesters, maar dit het nie so wyd gestrek soos die Leviete se kultiese bevoegdheid nie. Andersom gestel: die Levitiese priesters se bevoegdhede het oorvleuel met die koning se priesterlike mag, maar dit was beperk wat die koning se regeerfunksie betref het. Die koning was dus die enigste persoon in die land met koninklike en priesterlike funksies.

In 'n sekere sin herinner dit sterk aan Moses. As Leviet was hy tydens die volk se uittog uit Egipte regeerder van Israel, maar tog het hy 'n groot rol in die Israelitiese kultus gespeel as 'n leier met sekere priesterlike funksies.

\section{- Vers 5}

In teenstelling met vers 1 , staan die Here in vers 5 aan die koning se regterhand. In vers 1 het dit oor die koning se ereposisie as seun van God gegaan, maar nou gaan dit oor die ondersteuning wat die Here aan die koning bied binne 'n militêre situasie. In die $\mathrm{Ou}$ Testament is 'n persoon se regterhand dikwels 'n teken van sy mag en krag (vgl. Ps. 16:8; 109:31 en 121:5). Deurdat die Here aan die koning se regterhand staan, versterk hy die koning se regterhand en dus sy mag. Weer word hier gesinspeel op die Here se noue betrokkenheid in die vernietiging van die koning se vyande. Die digter praat van die dag as die Here kwaad word. In Israel het dag van die Here 'n besondere betekenis gehad. Vir hulle was dit die dag waarop God finaal met al Israel se vyande sou afreken en die volk in rus en vrede sou woon. 


\section{- Vers 6}

Hier word die Here, in aansluiting by vers 5, geteken as 'n Kryger.

Saam met sy aardse verteenwoordiger, tree die Here op om die vyande van Israel te vernietig.

In die Ou Testament gebeur dit dikwels dat die Here uitgebeeld word as 'n Kryger-koning. Voorbeelde hiervan kom voor in onder andere Rigters 7:20, waar gepraat word van die swaard van die Here. In Josua 5 word vertel van die leër van die Here. Ook in die verhaal van Bileam word vertel van die Engel van die Here wat met sy ontblote swaard staan. Jesaja 27:1 praat van die dag wat die Here sy skerp en sterk swaard gebruik. Volgens Jesaja 29 word die Here uitgebeeld as 'n krygsheer wat 'n stad beleër (vgl. Horbury, 1998:37 en 38).

\section{- Vers 7}

Daar twee moontlike maniere waarop hierdie vers verstaan kan word. Hiervolgens kan die beskrywing van die koning wat water drink óf dui op 'n militêre situasie, óf dit kan dui op 'n kultiese handeling. In 'n militêre situasie sou dit kon dui op die koning wat tydens die agtervolging van sy vyande, water uit 'n stroom langs die pad drink, opstaan en dan oor sy vyande triomfeer.

Sommige eksegete, soos Burden (1991:129) en Stuhlmueller (2002:80), meen egter dat die koning tydens sy salwingseremonie water gedrink het as deel van die kultiese handelinge wat plaasgevind het. In 1 Konings 1:38-40 word vertel van 'n salwingseremonie wat by die Gihonfontein plaasgevind het. By hierdie geleentheid sou die koning moontlik uit die fontein kon drink tydens sy inhuldiging. Albei hierdie verklarings kan inpas by die konteks van Psalm 110.

As agtergrond van Psalm 110 se militêre situasie, kan moontlik ook Israel se gebruik van "heilige oorloë" staan. Anderson (1975:171) wys daarop dat hierdie tipe oorloë gesien is as 'n godsdienstige aksie. Daar is geglo dat die Here self voor sy volk uittrek vir die geveg. In hierdie sin is die koning se gewapende optrede gesien as 'n middel waardeur die Here sy volk verlos (vers 3 ). In die heilige oorloë is die vyand gewoonlik met die banvloek getref (vers 6). Alles wat aan hulle behoort het, mens en dier, is dus vernietig. Hierdie vernietiging moes as 'n soort brandoffer aan die Here dien. 'n Verdere doel daarvan was om die "wraak van God" oor die vyand uit te oefen. Dit sluit aan by vers 5 wat praat van die dag as die Here kwaad word (Anderson, 1975:152, 171). Met die salwing van die nuwe koning, kyk die digter van Psalm 110 dus ook na die rol van 
die koning in die "heilige oorloë" van Israel. Dié Psalm kan as 'n versekering vir die koning dien dat hy beslis oor sy vyande sal triomfeer, omdat die Here self by die oorlog betrokke is en omdat die Here self hom aangestel het as koning van die Here se volk.

\section{Jesus Christus en Psalm $\mathbf{1 1 0}$}

Uit die voorafgaande behoort dit duidelik te wees dat Psalm 110 glad nie oor Jesus Christus handel nie, maar dat die aangesprokene in hierdie Psalm 'n Judese koning is, wat op die spoor van Melgisedek, priester en koning was.

In die Nuwe Testament is dit egter opvallend hoe verskillende skrywers Psalm 110 wel in terme van Jesus Christus verklaar (bv. Matt. 26:64; Hand. 2:34; 7:55; Rom. 8:34; Ef. 1:20; Hebr. 1:13; 5:6; $7: 11-25 ; 8: 1 ; 10: 12$ en 13$)$. Jesus Christus het na sy opstanding en hemelvaart aan die regterhand van God die Vader gaan sit. Jesus was ook priester, nie volgens die Levitiese wette nie, maar volgens die orde van Melgisedek, die priester-koning van Salem. Hierdie gebruik van Psalm 110 deur die Nuwe Testament sou daartoe lei dat die oud-Christelike tradisie Psalm 110 ook in terme van Jesus Christus verklaar. Volgens die eerste Christelike tradisie het Dawid, as outeur van Psalm 110, profeties opgetree. As profeet het hy vooruitgespreek van Jesus Christus as die komende Messias (vgl. Van der Ploeg, 1974:249). Dit sou egter té eensydig wees om die eie aard en boodskap van Psalm 110, soos wat die Ou Testament dit aanbied, buite rekening te laat, net omdat die Nuwe Testament dit in verband met Jesus Christus gebruik. Die vraag hoe Psalm 110 geïnterpreteer moet word, bring egter die hele debat oor watter eksegetiese model vir die Ou Testament gebruik moet word, weer na vore. Goldingay (1981:19) noem dat die verskillende hermeneutiese modelle eerder aanvullend tot mekaar gebruik moet word om die Ou Testament beter te verstaan. Die verskillende modelle verklaar Psalm 110 soos volg, in terme van Jesus Christus:

\subsection{Psalm 110 as geloofsoortuiging}

Hiervolgens lewer Psalm 110 'n stel geloofsbeginsels oor God en sy volk Israel aan die een kant en God en die Judese koning aan die ander kant. Die geloofsbeginsels wat hier betrokke is, is Sionsteologie en Israel se koningsideologie. Binne die raamwerk van Sionsteologie regeer die Here as die Groot koning vanaf Sionsberg. In die eerste plek regeer God oor sy uitverkore volk Israel en in die tweede plek oor die hele wêreld. As volk vergestalt Israel iets van God se koninkryk. In sy genade stel God 'n aardse 
verteenwoordiger aan om sy koningskap oor Israel te bevestig. Hierdie aardse verteenwoordiger vind gestalte in die Judese koning, as die gesalfde van God. As gesalfde van die Here is die koning die instrument waardeur die Here Israel verlos en beskerm. As priester het die koning die taak om God se reg en geregtigheid in Israel te handhaaf. Volgens Psalm 110 het God hierdie taak met 'n eed aan die Judese koning opgedra. Hierdie betrokke geloofsbeginsels van Psalm 110 het ontwikkel vanuit die vóór-Dawidiese era van die antieke stad, Salem.

God het dus onder sy volk gewerk deur sy instrument, die gesalfde priester-koning uit die nageslag van Dawid. Volgens die Tweede Testament werk God steeds deur 'n Priester-Koning uit die nageslag van Dawid, naamlik Jesus Christus. Deur Jesus word God se koningkap op die aarde gevestig deurdat Hy die Bose aan die kruis verslaan. As priester is Jesus meer as slegs 'n abstrakte priestersfiguur. As Priester volgens die orde van Melgisedek, offer Hy Homself om God se volk te verlos (vgl. Hebr. 9). In die Tweede Testament word God se uitverkore volk uitgebrei tot alle volke, nasies en tale. God se uitverkorenes vorm die kerk. As PriesterKoning verteenwoordig Jesus God se koningskap oor die kerk, net soos die Judese koning dit in die Eerste Testament gedoen het (vgl. Hebr. 7:26-28).

\subsection{Psalm 110 as lewenswyse}

Volgens hierdie model is die Ou Testament 'n boek wat hom besig hou met wat reg en verkeerd is in ooreenstemming met die Tora. Die Ou Testament handel dus oor die reg en geregtigheid van God. Binne hierdie breë raamwerk staan Psalm 110. As koningspsalm handel Psalm 110 oor ' $n$ Judese koning. In besonder is dit die koning van Psalm 110 se taak om God se reg en geregtigheid te handhaaf (vgl. Ps. 72). Volgens die Tweede Testament is dit egter Jesus Christus wat as Seun van God met die wêreld in gerig tree, om God se reg en geregtigheid te volbring.

Die Dawidiese konings vir wie Psalm 110 gesing is tydens die kroningseremonie, het egter gefaal in hulle taak om God se reg en geregtigheid te handhaaf. Weens die koning en die volk se sonde, is Israel in ballingskap weggevoer. Spanning het ontstaan tussen die koning se taak en sy eie sonde. Volgens die Tweede Testament is Jesus Christus die Een wat hierdie gespanne verhouding kom herstel. 


\subsection{Psalm 110 as heilsgeskiedenis}

God se ingryping in die geskiedenis tot redding van die gelowiges, behoort as sleutel van hierdie hermeneutiese model te dien. Die Ou Testament vertel die verhaal van God se sorg en redding. In Israel gee God in besonder sy redding en sorg aan die volk deur die Judese koning. Met sy militêre agtergrond, beklemtoon Psalm 110 in besonder Israel se verlossing van hulle vyande deur die optrede van God se gesalfde. Hierdie redding en sorg van God, strek egter baie wyer as net vir die volk Israel. Die Ou Testament stel dit duidelik dat die mensdom in sy geheel 'n verlosser nodig het. God self is hierdie Verlosser. As Verlosser-God tree God óf direk óf indirek op om te verlos. In Psalm 110 verlos God eerstens indirek deur die Judese koning, wat die opdrag kry om te heers oor sy vyande (vgl. Ps. 110:1). God verlos egter ook op 'n direkte wyse, deurdat Hyself óók betrokke is by die vernietiging van die vyand (vgl. Ps. 110:5 en 6). Volgens die Nuwe Testament verlos die Here deur Jesus Christus. In Jesus Christus word God se direkte en indirekte optrede verenig, omdat Jesus nie net God se verteenwoordiger op aarde was nie, maar omdat Hy self God was.

\subsection{Psalm 110 as 'n getuienis van Jesus Christus}

Volgens hierdie model is Jesus Christus self die sleutel tot dié verstaan van dié Psalm. Hiervolgens is die koning van Psalm 110 'n tipe van Jesus Christus wat sou kom. Alhoewel hierdie model kan bydra tot die beter verstaan van die Ou Testament, moet gewaak word teen onverantwoordelike spronge na Jesus Christus toe. Om eensydig te beweer dat Psalm 110 net op Jesus Christus dui, sou onwetenskaplik wees. So 'n eensydige standpunt sal in elk geval teen Goldingay se eie standpunt indruis, naamlik dat die verskillende hermeneutiese modelle sáám gebruik moet word.

\subsection{Psalm 110 as kanon}

Hiervolgens moet gekyk word na die ontstaan, ontwikkeling en herinterpretasie van dié Psalm. Daar kan aanvaar word dat Psalm 110 ontstaan het in die tyd toe Dawid die stad Jerusalem verower het, en hy volgens Jebusitiese wette priester-koning geword het. Hierdie Psalm is waarskynlik nie net ter herdenking van Dawid se koningskap gebruik nie, maar wel by al die Dawidiese konings se kroningseremonies. Dié Psalm roep elke keer die beeld van 'n ideale koning na vore. Dat die skrywers van die Nuwe Testament dus Psalm 110 herinterpreteer om Jesus Christus as die ideale Koning voor te hou, is logies. As God het Jesus die taak van die Ou- 
Testamentiese konings volkome volbring. Hy het gekom om God se uitverkore volk te verlos en om daarmee saam God se geregtigheid volmaak te volbring, deur die uitverkorenes weer in die regte verhouding tot God te plaas (vgl. Hebr. 4:14-16; 7 en 9).

\section{Jesus se priester- en messiasskap}

Jesus Christus se priesterskap is volgens die orde van Melgisedek. Wanneer in ag geneem word dat Jesus deur die Nuwe Testament voorgehou word as Seun van Dawid en Mattheus en Lukas Jesus se genealogie aan koning Dawid verbind (vgl. Matt. 1 en Luk. 3), kan aanvaar word dat Jesus 'n direkte afstammeling van Dawid was. Soos uiteengesit, is dit duidelik dat Dawid en sy nakomelinge priester-konings was volgens die orde van Melgisedek. Dit sou dus beteken dat Jesus Christus, as afstammeling van Dawid, net soos sy aardse voorvader, ook 'n priester-koning kon wees. Moontlik het die Hebreërskrywer hierdie fout ook besef en dit gebruik om Jesus se messiasskap te bevestig.

\section{Gevolgtrekking}

Alles in ag genome, kan aanvaar word dat nie net Jesus Christus aan Psalm 110 betekenis gee nie, maar dat die Dawidiese konings, as priester-konings, ook as die inhoud van Psalm 110 kan dien. Tog behoort die Christenleser te aanvaar dat Jesus Christus uiteindelik die Priester-Koning is, net soos die Judese konings dit van Israel was. As volmaakte Seun van God het Jesus die verhouding van God se uitverkorenes met die Here kom regmaak, deur Homself daarvoor aan die kruis te offer. Hy is dus die kerk - as die uitverkore volk van die Here in die Nuwe Testament - se Verlosser, net soos die Judese koning dit van Israel was.

\section{Geraadpleegde bronne}

ANDERSON, B.W. 1957 [1975]. Understanding the Old Testament. 3rd ed. New Jersey: Prentice-Hall.

ANDERSON, G.W., eds. 1979. Tradition and interpretation: essays by members of the Society for Old Testament Study. Oxford: Clarendon.

BOSHOFF, W., SCHEFFLER, E. \& SPANGENBERG, I. 2000. Ancient Israelite literature in context. Pretoria: Protea Boekhuis.

BURDEN, J.J. 1991. Skrifuitleg vir Bybelstudente en gemeente: Psalms 101119. Kaapstad: NG Kerk Uitgewers.

DE VAUX, R. 1961 [1991]. Ancient Israel, its life and institutions. 2nd ed. Wiltshire: Redwood.

GOLDINGAY, J. 1981. Approaches to Old Testament interpretation. Leicester: InterVarsity. 
HINSON, D.F. 1990 [1997]. History of Israel. Cambridge: Cambridge University Press.

HORBURY, W. 1998. Jewish Messianism and the cult of Christ. London: SCM.

JOHNSON, A.R. 1955. Sacral kingship in ancient Israel. Cardiff: Cardiff University of Wales Press.

KEEL, O. 1972 [1977]. Der Welt der alterientalischen Bildsymbolik und das Alte Testament: am Beispiel der Psalmen. Benziger: Neukirchener Verlag.

KRAUS, H.J. 1960. Biblischer Kommentar Altes Testament: Psalmen. Band $\mathrm{XV} / 2$. Wageningen: Veenman.

PRINSLOO, W.S. 1988. Psalm 110. (In Burger, C.W., Müller, B.A. \& Smit, D.J., reds. Woord teen die lig, II/4. Riglyne vir prediking oor die Psalms. Kaapstad: NG Kerk Uitgewers. p. 174-181.)

STUHLMUELLER, C.P. 2002. The spirituality of the Psalms. Minnesota: The Liturgical Press.

VAN DER PLOEG, J.P.M. 1974. Psalmen. Deel II. Roermond: Romen.

ZIMMERLI, W. 1978 [1987]. Old Testament theology in outline. Edinburgh: John Knox.

\section{Kernbegrippe:}

koningspsalm

priester-koning

priesterorde van Melgisedek

Salem

\section{Key concepts:}

priest-king priestly order of Melchizedek

royal psalm

Salem 